\title{
Antibacterial Activity of the Cream Preparation from Theobroma cacao L. Pod Aqueous Extract
}

\author{
Ethel Andrea C. Ladignon and Jocelyn S. Bautista-Palacpac \\ Department of Industrial Pharmacy, College of Pharmacy, University of the Philippines Manila
}

\begin{abstract}
Background and Objectives. While Theobroma cacao $L$ has long been utilized in the food, cosmetic, and pharmaceutical industries, it was also found to possess antibacterial activity. The beans comprise $10 \%$ of the fruit, while the remaining $90 \%$, consisting of pods, is considered waste. It was reported that the pods possess antibacterial activity, and if utilized for this purpose, T. cacao pods will no longer be considered as waste. The aim of this study was to evaluate the antibacterial activity of the cream formulated from the aqueous extract of T. cacao L pods.

Methods. The milled T. cacao pods were extracted using distilled water at $4^{\circ} \mathrm{C}$ for 24 hours. The crude extract was subjected to liquid-liquid partitioning using hexane, ethyl acetate, and n-butanol. Phytochemical screening was performed to identify the constituents present in the extract and its fractions. The extract and its fractions were tested against Staphylococcus aureus, Staphylococcus epidermidis, and Pseudomonas aeruginosa. Determination of $\mathrm{IC}_{50}$ using 3,5-dimethylthiazol-2-yl)-2,5-diphenyltetrazolium bromide (MTT) Reduction Assay was used to evaluate the antibacterial activity. The extract with the highest yield and the highest antibacterial activity were formulated into a cream. T. cacao cream was evaluated with quality control tests for creams and emulsions. Acute skin irritation test was performed on the T. cacao cream to assess skin irritability upon application on adult male albino rabbits.
\end{abstract}

Results. T. cacao crude extract and its fractions possessed antibacterial activity. Among the fractions tested, n-butanol fraction had the highest activity against S. aureus, S. epidermidis, and P. aeruginosa. There was a significant difference between the fractions tested on the three bacterial strains $(p<0.05)$. Although $\mathrm{n}$-butanol fraction had the highest activity, the actual yield obtained after extraction was $0.95 \%$. Since T. cacao aqueous extract also exhibited good antibacterial activity, it was chosen for the formulation study. There was no significant difference between the $I_{50}$ of the $T$. cacao crude extract and the $I C_{50}$ of $T$. cacao cream, hence formulating it into a cream did not affect the antibacterial activity of the extract.

Conclusion. T. cacao pod extract, as well as its fractions, possessed antibacterial activity against three bacterial strains. The T. cacao cream produced was a water-in-oil, non-irritant cream with antibacterial activity, and with acceptable physical attributes.

Key Words: Theobroma cacao, T. cacao cream, IC $C_{50}$ MTT, antibacterial activity

\section{INTRODUCTION}

Corresponding author: Ethel Andrea C. Ladignon, RPh, MS Department of Industrial Pharmacy College of Pharmacy

University of the Philippines Manila

Taft Avenue, Manila 1000, Philippines

Email: ecladignon1@up.edu.ph
Skin infection is one of the most prevalent diseases in tropical areas such as the Philippines, varying in symptoms and severity. ${ }^{1}$ The Philippine Dermatological Society considers the following as common skin conditions: acne, contact dermatitis, eczema, psoriasis, and warts; ${ }^{2}$ acne and warts are skin infections. Causative agents include bacteria such as Staphylococcus, Corynebacterium, Brevibacterium, Propionibacterium, Acinetobacter, Escherichia, Salmonella, Pseudomonas, and Yersinia species, ${ }^{3}$ as well as other microorganisms such as fungi and viruses. 
Although most skin infections have low mortality rates as compared to other diseases, treatment of such conditions should be met to prevent progression of the disease such as disfigurement of body parts and systemic infections that may lead to death. ${ }^{1}$ Skin infections are treated with antibiotics and other antimicrobials, such as fusidic acid, clindamycin, benzoyl peroxide, silver sulfadiazine and mupirocin, and they are usually available for topical use such as creams, ointments, and gels. Tablets, capsules, and parenteral preparations are used for systemic treatment. However, some of these antimicrobials, particularly topical preparations, can cause itching, burning sensation, and skin irritation that may interfere in treating the infection. ${ }^{3}$

Recent studies showed that some plants may be used as alternative treatment for skin infections and were indeed found to possess antimicrobial activity. In Asian countries, such as India and China, herbal preparations are preferred more than synthetic products due to their availability and accessibility. ${ }^{4}$ In the Philippines, among the plants used for their antimicrobial property are Psidium guajava, Piper betle, and Senna alata. ${ }^{5}$ Recent studies from other countries showed that Theobroma cacao is among the plants shown to have antibacterial activity. 6

Theobroma cacao Linne is a small tree (3 to 5 meters in height) cultivated at low and medium altitudes. In the Philippines, cacao trees are abundant in Quezon, Laguna, Batangas, Cavite, Camarines Sur, and the Davao region. The fruit is oblong, 10 to 15 centimeters long, prominently wrinkled, yellow or purplish, and the seeds are numerous and embedded in whitish pulp. ${ }^{8}$

T. cacao has been utilized in the food and pharmaceutical industries, and was also found to possess antibacterial activity. The beans comprise $10 \%$ of the fruit, while the remaining $90 \%$ consisting of the pod are considered waste. It was reported that the pods also possess antibacterial activity, and if utilized for this purpose, T. cacao pods will no longer be considered as waste.

T. cacao pods contain hemicellulose, flavonoids, tannins and fatty acids, polysaccharides, polyphenols, steroids, terpenes, amino acids, and alkaloids such as theobromine. ${ }^{9}$ Most of these constituents elicit antibacterial activity, both the aqueous crude extract and some of its fractions. ${ }^{6,7}$

An antimicrobial assay of T. cacao pods using agar well diffusion method showed zone of inhibition against four bacterial strains namely, Staphylococcus aureus, Salmonella sp., Klebsiella pneumoniae, and Pseudomonas aeruginosa. ${ }^{6}$

In addition, a microdilution method was performed in the aqueous crude extract (with a yield of $6.55 \%$ from the dried pods) of T. cacao pods. It was fractionated by solvent partitioning with polar solvent extraction. It was found in the study that the crude extract exhibited antibacterial activity against $P$. aeruginosa and Salmonella enterica Serotype Choleraesuis (with a minimum inhibitory concentration (MIC) of $5.0 \mathrm{mg} / \mathrm{mL}$ ), although at doses of up to $10 \mathrm{mg} /$ $\mathrm{mL}$, it was not effective against the gram-positive bacteria.
Sub-fractions varied widely in activity and strongest antibacterial activity was seen with CHE8 (methanol:water) against $S$ enterica (MIC of $1.0 \mathrm{mg} / \mathrm{mL}$ ) and with CHE9 (n-butanol:water) against S. epidermidis (MIC of 2.5 $\mathrm{mg} / \mathrm{mL}$ ). The fractions contained flavonoids, phenolic compounds, steroids, terpenes, amino acids, and alkaloids. ${ }^{7}$

The aim of this study was to evaluate the antibacterial activity of the cream prepared from the aqueous extract of T. cacao pods. Specifically, this study aimed to: 1 ) identify the possible constituents of $T$. cacao aqueous extract through phytochemical screening, and 2) determine the antibacterial activity of the extract and its fractions.

\section{METHODS}

\section{Collection, authentication, and processing}

Ten kilograms of fresh Theobroma cacao fruits were collected from Quezon province last July 2015. The fruit was authenticated by the Bureau of Plant Industry, Manila.

The pods were collected from the fresh fruits and comminuted into small pieces. The comminuted pods were dried in an oven (STOKES Model $38-\mathrm{B}$ ) at $60^{\circ} \mathrm{C}$ and milled using a beater mill (Retsch Rotor Beater Mill Type SR2) screened with mesh no. 2. The milled pods were used for raw material quality control tests and for the extraction process.

\section{Extraction and liquid-liquid partitioning of T. cacao pods}

Three hundred grams of Tcacao pods were extracted in $3,000 \mathrm{~mL}$ of distilled water for 24 hours at $4^{\circ} \mathrm{C}$. The aqueous extract was lyophilized and used for liquid-liquid partitioning, phytochemical screening, and antibacterial assay.

Liquid-liquid partitioning was employed to T. cacao extract (CE) by extraction with n-butanol (CE1) ( 3 x 30 $\mathrm{mL})$, ethyl acetate $(\mathrm{CE} 2)(3 \times 30 \mathrm{~mL})$, and hexane (CE3) $(3 \times 30 \mathrm{~mL})$; the remainder was the water fraction (CE4). All fractions were evaporated in vacuo at $40^{\circ} \mathrm{C}$ and were subjected to phytochemical screening and antibacterial activity testing.

\section{Characterization of T. cacao pods and extract}

Limit and identification tests, such as macroscopic evaluation, determination for loss on drying (water content), total ash, acid-insoluble ash, water-soluble ash, and total extractives, were performed on the milled pods. ${ }^{10,11}$

Phytochemical screening was performed in $\mathrm{CE}$, $\mathrm{CE} 1, \mathrm{CE} 2, \mathrm{CE} 3$, and $\mathrm{CE} 4$ to assess the presence of carbohydrates (using Molisch, Fehling's, Seliwanoff, and Tollen's phloroglucinol tests), anthraquinone glycosides (Shouteten and Modified Bornträger Test), tannins and phenolic glycosides (gelatin and ferric chloride tests), cardiac glycosides (Salkowski and Liebermann-Burchard tests), saponins (froth test), flavonoids (Shinoda test, concentrated 
sulfuric acid, and $10 \% \mathrm{NaOH}$ ), cyanogenic glycosides (sodium picrate), and alkaloids (Mayer's, Dragendorff's, Valser's, and Wagner's tests). ${ }^{12}$

\section{Antibacterial activity test using MTT Reduction Assay}

\section{Preparation of the test pathogens}

Three bacterial strains were used in this study: Staphylococcus aureus ATCC ${ }^{\circledR} 25923$ (Sa), Staphyloccocus epidermidis (Se) ATCC ${ }^{\circledR} 12228$, and Pseudomonas aeruginosa ATCC $^{\circledR} 27853(\mathrm{~Pa})$. These bacterial strains were cultured in Mueller-Hinton agar (MHA) at $37^{\circ} \mathrm{C}$ for 24 hours and stored in the refrigerator $\left(5^{\circ}-8^{\circ} \mathrm{C}\right)$ until use. ${ }^{13}$ The bacterial cultures were further inoculated on Mueller-Hinton broth (MHB) and were incubated at $35^{\circ}-37^{\circ} \mathrm{C}$ until the visible turbidity was equal to $0.5 \mathrm{McF}$ arland Standard $\left(1.5 \times 10^{8} \mathrm{CFU} / \mathrm{mL}\right)$. The optical density of the bacterial suspensions was adjusted to 0.1 and was diluted with $30 \mathrm{~mL}$ fresh MHB..$^{14,15,16}$

\section{Preparation of extract working solutions}

Stock solutions were prepared at a concentration of $2 \mathrm{mg} / \mathrm{mL}$ using each of the extracts employing $1 \%$ dimethylsulfoxide (DMSO) as solvent with $\mathrm{pH} 7.4$ phosphate buffer. ${ }^{17}$ These solutions were filtered using $0.20 \mu \mathrm{m}$ syringe filter. An aliquot of the prepared stock solutions was adjusted to final concentrations of 30,70 , and $150 \mu \mathrm{g} / \mathrm{mL}$. Clindamycin was used as a positive control and was dissolved in $\mathrm{pH} 7.4$ phosphate buffer, and further diluted to their final concentrations of 4,6 and $8 \mu \mathrm{g} / \mathrm{mL} .{ }^{16}$ As negative control, $1 \%$ DMSO was used.

\section{Antibacterial activity test using MTT Reduction Assay}

Two microliters of the extract was added to each well of the plate. The same amount $(2 \mu \mathrm{L})$ of $1 \%$ DMSO and clindamycin was dispensed on the wells labelled as DMSO and $\mathrm{Cln}$, respectively. Ninety-eight microliters of MHB was dispensed on all wells, except on well labelled as MHB. One hundred microliters of the prepared bacterial cell suspensions were dispensed on wells except on wells labelled as MHB and as test pathogens $(\mathrm{Sa}, \mathrm{Se}, \mathrm{Pa})$. On the wells labelled as $\mathrm{MHB}$ (medium blank), MTT (dye blank), and test pathogens, $100 \mu \mathrm{L}$ of MHB, MTT, and the prepared bacterial cell suspensions were dispensed, respectively. The plates were covered and incubated for 12 to 15 hours at $35^{\circ}-37^{\circ} \mathrm{C}$. After incubation, $20 \mu \mathrm{L}$ of $0.5 \% \mathrm{w} / \mathrm{v}$ of 3,5-dimethylthiazol-2-yl)2,5-diphenyltetrazolium bromide (MTT), dissolved in $\mathrm{pH}$ 7.4 buffer, was added to each well and allowed to incubate for another 4 hours at room temperature. Fifty microliters of $1 \%$ DMSO was added to each well with gentle swirling to dissolve the purple formazan crystals. ${ }^{17}$ Five percent hydrogen peroxide was added to each well to inactivate the bacteria. Absorbance values at $595 \mathrm{~nm}$ was measured and recorded using a CLARIOstar ${ }^{\circledR}$ monochromator microplate reader. The percent (\%) inhibition was calculated as:

$\%$ inhibition $=\{1-[$ Abs of extract $w /$ bacteria $-($ Abs of extract - Mean abs of MHB)] / [Mean abs of DMSO Mean abs of MHB] x 100

The $\mathrm{IC}_{50}$ was calculated using a single linear regression between the percent inhibition of each extract versus the concentration point of the extract. Three trials and four replicates were done in this test.

\section{Formulation of cream}

Fifty grams of a water-in-oil cream was produced using T. cacao extract with compatible excipients. Each of the oil-soluble emulsifiers was dissolved in the oil phase and heated at $70^{\circ} \mathrm{C}$. The oil phase was labeled as Mixture A. Each of the water-soluble emulsifiers and preservatives, on the other hand, was dissolved in the aqueous phase, heated at $75^{\circ} \mathrm{C}$. and labeled as Mixture B. Mixture B was added to Mixture $\mathrm{A}$ in portions with continuous stirring using a

Table 1. Summary matrix of trial formulations

\begin{tabular}{|c|c|c|c|c|c|c|}
\hline \multirow{2}{*}{ Ingredient } & \multicolumn{6}{|c|}{ Amount (\%) } \\
\hline & Trial 1 & Trial 2 & Trial 3 & Trial 4 & Trial 5 & Trial 6 \\
\hline T. cacao crude extract & 10.0 & 10.0 & 10.0 & 10.0 & 10.0 & 10.0 \\
\hline Glyceryl monostearate & $1.0-15.0$ & $1.0-15.0$ & $1.0-15.0$ & $1.0-15.0$ & $1.0-15.0$ & $1.0-15.0$ \\
\hline Lanolin & $1.0-15.0$ & - & - & - & - & - \\
\hline Mineral oil, Light & - & $1.0-20.0$ & $1.0-20.0$ & $1.0-20.0$ & $1.0-20.0$ & $1.0-20.0$ \\
\hline Sorbitan monopalmitate (Span 40) & - & $1.0-15.0$ & $1.0-15.0$ & $1.0-15.0$ & $1.0-15.0$ & $1.0-15.0$ \\
\hline Polyoxyethylene glycol monopalmitate (Tween 40) & $1.0-15.0$ & - & - & - & $1.0-15.0$ & $1.0-15.0$ \\
\hline Cetostearyl alcohol & - & - & $1.0-10.0$ & $1.0-10.0$ & $1.0-10.0$ & - \\
\hline Stearyl alcohol & - & $1.0-10.0$ & - & - & - & - \\
\hline Ethylene glycol monostearate & - & $1.0-10.0$ & - & - & - & - \\
\hline Sodium benzoate & $0.1-1.0$ & $0.1-1.0$ & - & - & - & - \\
\hline Methyl paraben & - & - & $0.1-1.0$ & $0.1-1.0$ & $0.1-1.0$ & $0.1-1.0$ \\
\hline Propyl paraben & - & - & $0.1-1.0$ & $0.1-1.0$ & $0.1-1.0$ & $0.1-1.0$ \\
\hline Purified water qs. ad. & 100.0 & 100.0 & 100.0 & 100.0 & 100.0 & 100.0 \\
\hline
\end{tabular}


Table 2. Rating scale for acute skin irritation test based on OECD Guidelines 404

\begin{tabular}{ll}
\hline no erythema & 0 \\
\hline very slight erythema & 1 \\
\hline well defined erythema & 2 \\
\hline moderate to severe erythema & 3 \\
\hline $\begin{array}{l}\text { severe erythema (beet redness) to slight eschar formation } \\
\text { (injuries in depth) }\end{array}$ & 4
\end{tabular}

Heidolph mixer (Model RZR 2020) at speed 7, range II until a homogenous cream was obtained (Table 1).

Six trial formulations were evaluated based on their appearance, odor, color, texture, spreadability, homogeneity, viscosity, and $\mathrm{pH}$. Quality control tests for emulsions, such as dye solubility, dilution, conductivity, $\mathrm{CoCl}_{2}$ filter paper, and fluorescence tests, were also performed to confirm if the formulated cream was oil-in-water or water-in-oil. Based on the evaluation of these attributes, the best formulation was chosen and was scaled-up to 100 grams. The final product was packaged in a $30-g$ plastic jar.

\section{Antibacterial activity of T. cacao cream}

The same procedure for the antibacterial activity test was applied for the formulated cream. A cream base was utilized as negative control.

\section{Acute skin irritation test}

Acute dermal skin irritation based on OECD Guidelines Test no. 404 was performed using T. cacao cream. Six adult male albino rabbits (weighing 1.5 to $2.0 \mathrm{~kg}$ ) were used for this test. One group consisted of three albino rabbits labeled as non-abraded group, while the remaining set of three rabbits, was labeled as the abraded group. A portion of the body of the male albino rabbits of both groups were gently shaved to expose their skin. Dermal abrasion was performed by scratching the exposed skin of the abraded group; no scratching was performed in the non-abraded group. Distilled water was used as negative control, and application of the $T$. cacao cream was performed on the non-abraded and abraded skin portion of the albino rabbits; observation of edema and erythema was evaluated after fourteen days (Table 2).

The procedure was conducted at the Industrial Technology Development Institute-Standards and Testing Division, Department of Science and Technology (ITDISTD-DOST).

\section{Statistical analysis}

Statistical software used to verify for significant differences between the fractions and the formulation was STATA IC 13. Based on the design of experiment, KruskalWallis Test was used for the $\mathrm{IC}_{50} \mathrm{~s}$ of different fractions (CE, CE1, CE2, CE3, and CE4) tested. Independent two-tailed student $\mathrm{t}$-test was used for comparing the $\mathrm{IC}_{50} \mathrm{~s}$ between the chosen fraction for formulation of cream and the formulated cream.

\begin{tabular}{ll}
\hline no edema & 0 \\
\hline very slight edema & 1 \\
\hline slight edema (edges of area well defined by definite raising) & 2 \\
\hline moderate edema (raised approximately $1 \mathrm{~mm}$ ) & 3 \\
\hline $\begin{array}{l}\text { severe edema (raised more than } 1 \mathrm{~mm} \mathrm{\&} \mathrm{extending} \mathrm{beyond} \\
\text { area of exposure) }\end{array}$ & 4
\end{tabular}

\section{RESULTS}

\section{Characterization of Theobroma cacao pods and aqueous extract}

Fresh Theobroma cacao fruits weighed 9,998.1 grams upon collection (Figure 1). The fruits after collection were yellow in color with dark brown striations and measured $15-25 \mathrm{~cm}$. The pods were removed from the fruit and collected. The pods were garbled and dried in an oven at $55 \pm 5^{\circ} \mathrm{C}$. Drying temperature was maintained to prevent possible degradation of constituents of the pods. Both the exterior and the interior part of the dried pods appeared brown in color, felt brittle, and were with a distinct sweet odor. The pods, based on macroscopic evaluation, were ovoid in shape, pointed, and constricted at the base with five prominent furrows (Figure 2). The actual weight of dried milled pods was 7,642.3 grams and actual yield obtained was $76.44 \%$, calculated from the fresh fruit.

The yield of $T$. cacao pod aqueous extract from the dried pods was $5.20 \%$, calculated on a dried basis. Cold maceration obtained a light brown-colored solution with a $\mathrm{pH}$ of 6.16. The actual yield of the fractions consisted of $0.95 \%$ of $\mathrm{CE} 1,0.76 \%$ of $\mathrm{CE} 2,0.57 \%$ of $\mathrm{CE} 3$ and $2.92 \%$ of $\mathrm{CE} 4$, calculated on a dried basis.

The pods were also tested for total ash, total extractives, moisture content, and loss on drying (Table 3).

Table 3. Results obtained from limit and identification tests for articles of botanical origin based on the Philippine Pharmacopeia I and WHO Guidelines

\begin{tabular}{lr} 
Test & Result \\
Loss on drying & $16.72 \%$ \\
Moisture content & $10.45 \%$ \\
Total ash & $8.56 \%$ \\
Acid-insoluble ash & $3.85 \%$ \\
Water-soluble ash & $7.07 \%$ \\
Alcohol-soluble extractives & $10.15 \%$ \\
Water-soluble extractives & $17.32 \%$ \\
\hline
\end{tabular}

Phytochemical screening showed that T. cacao extract (CE) contains alkaloids, carbohydrates, reducing sugars, flavonoids, tannins, and cardiac glycosides. All of these fractions contained tannins, except for CE3. Flavonoids were only observed in CE, CE1, and CE2. Fraction CE3 only contained cardiac glycosides (Table 4). 


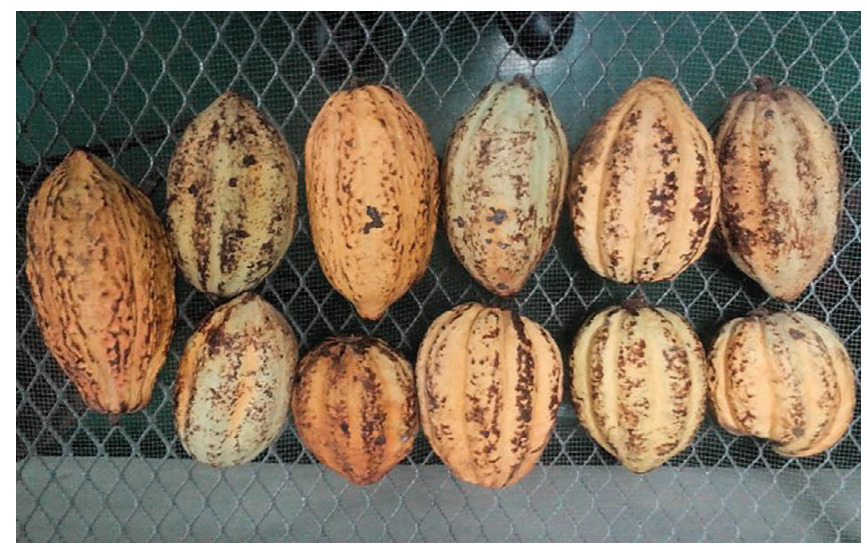

Figure 1. Fresh T. cacao fruits after collection from Quezon province $(0.1 x)$.

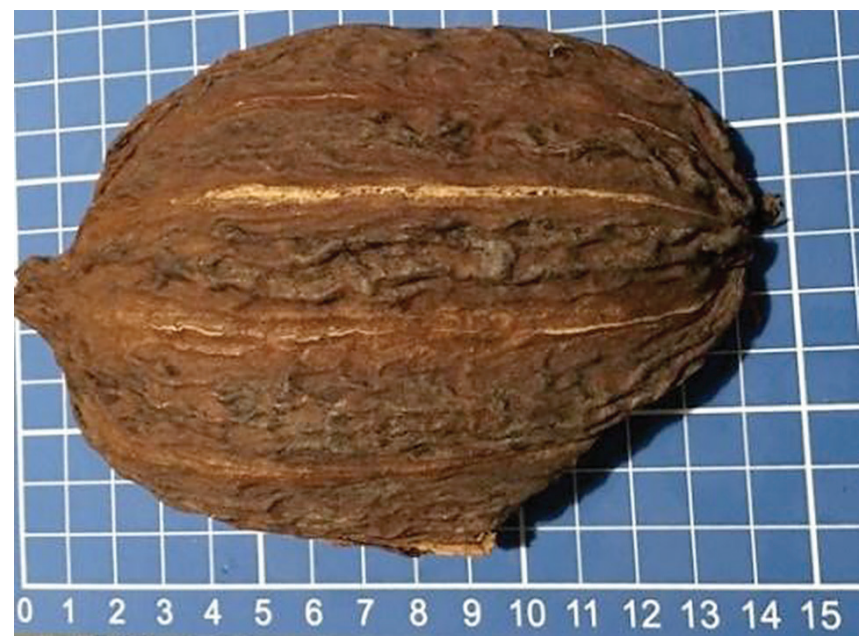

Figure 2. Dried T. cacao pod.

\section{Antibacterial activity test using MTT Reduction Assay}

The crude extract and its fractions showed antibacterial activity inhibition. Among the fractions tested, CE1 (n-butanol) fraction had the highest antibacterial activity against 3 bacterial strains, namely, S. aureus, S. epidermidis, and $P$. aeruginosa (Table 4). There was a significant difference between the fractions tested on three bacterial strains tested $(p<0.05)$.

\section{Formulation of cream}

The $T$. cacao cream produced during the trial formulation was a homogenous, off-white, and non-gritty cream with acceptable spreadability $(6.5 \mathrm{~mm}), \mathrm{pH}(6.5)$, and with a greasy feel (Table 5). The formulation was scaledup to 100 grams for use in the antibacterial activity and acute skin irritation tests. The final product was packaged in a $30-g$ plastic jar. Emulsion quality control parameters were performed on the formulated cream. The T. cacao cream produced was a water-in-oil type, since the results conformed to the water-in-oil emulsion physical attributes (Table 6).

\section{Antibacterial activity of T. cacao cream}

Antibacterial activity test was also performed in T. cacao cream (Table 7). Based on the results, there was no significant difference between $\mathrm{CE}$ and the cream $(p>0.05)$.

\section{Acute skin irritation test}

The analysts of ITDI-STD-DOST submitted the tabulated results obtained from the acute skin irritation test. No images of the test were given after the test.

The T. cacao cream tested on the non-abraded group

Table 4. $I_{50}$ of T. cacao extract and its fractions with possible constituents responsible for the antibacterial activity

\begin{tabular}{|c|c|c|c|c|}
\hline \multirow{2}{*}{ Fraction } & \multicolumn{3}{|c|}{$I C_{50}(\mu \mathrm{g} / \mathrm{mL})$} & \multirow{2}{*}{ Constituent/s } \\
\hline & S. aureus & S. epidermidis & P. aeruginosa & \\
\hline CE & $\begin{array}{l}58.81 \pm 0.89 \\
57.95 \pm 0.52 \\
59.72 \pm 0.29 \\
58.76 \pm 1.10\end{array}$ & $\begin{array}{l}72.58 \pm 1.24 \\
72.86 \pm 1.08 \\
71.22 \pm 1.57 \\
73.67 \pm 3.47\end{array}$ & $\begin{array}{l}52.48 \pm 4.90 \\
48.46 \pm 2.25 \\
57.93 \pm 2.78 \\
51.04 \pm 2.33\end{array}$ & $\begin{array}{l}\text { carbohydrates, reducing } \\
\text { sugars, flavonoids, tannins, } \\
\text { cardiac glycosides, alkaloids }\end{array}$ \\
\hline CE1 & $\begin{array}{l}46.22 \pm 0.06 \\
46.20 \pm 0.27 \\
46.29 \pm 0.35 \\
46.17 \pm 0.73 \\
\end{array}$ & $\begin{array}{l}63.98 \pm 0.58 \\
64.30 \pm 1.08 \\
63.31 \pm 0.40 \\
64.33 \pm 0.45 \\
\end{array}$ & $\begin{array}{l}44.10 \pm 1.73 \\
42.15 \pm 1.07 \\
45.42 \pm 2.57 \\
44.72 \pm 0.50\end{array}$ & $\begin{array}{l}\text { flavonoids, tannins, } \\
\text { cardiac glycosides, alkaloids }\end{array}$ \\
\hline CE2 & $\begin{array}{l}77.49 \pm 1.03 \\
76.73 \pm 1.24 \\
78.67 \pm 1.78 \\
77.07 \pm 0.62 \\
\end{array}$ & $\begin{array}{l}70.35 \pm 0.97 \\
70.20 \pm 0.22 \\
69.47 \pm 1.23 \\
71.39 \pm 2.16 \\
\end{array}$ & $\begin{array}{l}55.53 \pm 3.84 \\
53.45 \pm 1.67 \\
53.18 \pm 0.96 \\
59.96 \pm 1.49 \\
\end{array}$ & $\begin{array}{l}\text { flavonoids, tannins, } \\
\text { cardiac glycosides }\end{array}$ \\
\hline CE3 & $\begin{array}{l}94.67 \pm 0.57 \\
95.26 \pm 2.49 \\
94.06 \pm 1.22 \\
94.12 \pm 1.13 \\
\end{array}$ & $\begin{array}{l}86.62 \pm 0.94 \\
86.79 \pm 4.19 \\
87.46 \pm 1.28 \\
85.61 \pm 1.99 \\
\end{array}$ & $\begin{array}{c}190.88 \pm 18.97 \\
207.88 \pm 3.54 \\
194.35 \pm 2.91 \\
170.42 \pm 4.77\end{array}$ & cardiac glycosides \\
\hline CE4 & $\begin{array}{l}58.86 \pm 0.61 \\
58.89 \pm 0.61 \\
59.46 \pm 2.44 \\
58.23 \pm 1.00\end{array}$ & $\begin{array}{l}68.97 \pm 0.34 \\
69.26 \pm 1.65 \\
69.06 \pm 0.60 \\
68.59 \pm 2.35\end{array}$ & $\begin{array}{l}71.03 \pm 1.06 \\
71.78 \pm 1.94 \\
69.82 \pm 0.80 \\
71.51 \pm 0.94\end{array}$ & $\begin{array}{l}\text { carbohydrates, } \\
\text { reducing sugars, tannins }\end{array}$ \\
\hline
\end{tabular}


Table 5. Physical attributes of T. cacao cream

\begin{tabular}{|c|c|c|c|c|c|c|}
\hline Test Parameter & Trial 1 & Trial 2 & Trial 3 & Trial 4 & Trial 5 & Trial 6 \\
\hline Appearance & off-white & off-white & off-white & off-white & off-white & off-white \\
\hline Odor & light sweet odor & light sweet odor & light sweet odor & light sweet odor & light sweet odor & light sweet odor \\
\hline Texture & $\begin{array}{c}\text { greasy, sticky, } \\
\text { non-gritty }\end{array}$ & $\begin{array}{c}\text { non-greasy, } \\
\text { gritty }\end{array}$ & $\begin{array}{c}\text { greasy, } \\
\text { non-gritty }\end{array}$ & $\begin{array}{l}\text { less greasy, } \\
\text { non-gritty }\end{array}$ & $\begin{array}{c}\text { greasy, } \\
\text { non-gritty }\end{array}$ & $\begin{array}{l}\text { less greasy, } \\
\text { non-gritty }\end{array}$ \\
\hline Spreadability (mm) & 6.0 & 5.0 & 7.0 & 7.0 & 7.0 & 6.5 \\
\hline Homogeneity & homogenous & homogenous & homogenous & homogenous & homogenous & homogenous \\
\hline $\mathrm{pH}$ & 6.80 & 7.0 & 6.20 & 6.25 & 6.5 & 6.5 \\
\hline Viscosity & pseudoplastic & pseudoplastic & pseudoplastic & pseudoplastic & pseudoplastic & pseudoplastic \\
\hline Dye solubility (methyl red) & orange globules & yellow cream & pink globules & pink globules & pink globules & pink globules \\
\hline Dilution & $\begin{array}{c}\text { formation of } \\
\text { two-layers }\end{array}$ & dilution of cream & $\begin{array}{c}\text { formation of } \\
\text { two-layers }\end{array}$ & $\begin{array}{c}\text { formation of } \\
\text { two-layers }\end{array}$ & $\begin{array}{c}\text { formation of } \\
\text { two-layers }\end{array}$ & $\begin{array}{c}\text { formation of } \\
\text { two-layers }\end{array}$ \\
\hline Conductivity & $\begin{array}{l}\text { bulb did not } \\
\text { light up }\end{array}$ & bulb lighted up & $\begin{array}{l}\text { bulb did not } \\
\text { light up }\end{array}$ & $\begin{array}{l}\text { bulb did not } \\
\text { light up }\end{array}$ & $\begin{array}{l}\text { bulb did not } \\
\text { light up }\end{array}$ & $\begin{array}{l}\text { bulb did not } \\
\text { light up }\end{array}$ \\
\hline $\mathrm{CoCl}_{2}$ filter paper & $\begin{array}{c}\text { red spots on } \\
\text { blue filter paper }\end{array}$ & $\begin{array}{l}\text { blue filter } \\
\text { turned red }\end{array}$ & $\begin{array}{c}\text { red spots on } \\
\text { blue filter paper }\end{array}$ & $\begin{array}{c}\text { red spots on } \\
\text { blue filter paper }\end{array}$ & $\begin{array}{c}\text { red spots on } \\
\text { blue filter }\end{array}$ & $\begin{array}{c}\text { red spots on } \\
\text { blue filter }\end{array}$ \\
\hline Fluorescence & fluorescence & $\begin{array}{c}\text { spotty } \\
\text { fluorescence } \\
\end{array}$ & fluorescence & fluorescence & fluorescence & fluorescence \\
\hline
\end{tabular}

Table 6. Emulsion Quality Control tests of T. cacao cream

\begin{tabular}{|c|c|c|c|c|c|c|}
\hline Formulation & $\begin{array}{l}\text { Dye solubility } \\
\text { (methyl red) }\end{array}$ & Dilution & Conductivity & $\mathrm{CoCl}_{2}$ filter paper & Fluorescence & Remark \\
\hline Trial 1 & orange globules & $\begin{array}{c}\text { formation of } \\
\text { two-layers }\end{array}$ & bulb did not light up & $\begin{array}{l}\text { red spots on blue } \\
\text { filter paper }\end{array}$ & fluorescence & W/O emulsion \\
\hline Trial 2 & yellow cream & dilution of cream & bulb lighted up & blue filter turned red & $\begin{array}{c}\text { spotty } \\
\text { fluorescence }\end{array}$ & $\mathrm{O} / \mathrm{W}$ emulsion \\
\hline Trial 3 & pink globules & $\begin{array}{c}\text { formation of } \\
\text { two-layers }\end{array}$ & bulb did not light up & $\begin{array}{l}\text { red spots on blue } \\
\text { filter paper }\end{array}$ & fluorescence & W/O emulsion \\
\hline Trial 4 & pink globules & $\begin{array}{c}\text { formation of } \\
\text { two-layers }\end{array}$ & bulb did not light up & $\begin{array}{l}\text { red spots on blue } \\
\text { filter paper }\end{array}$ & fluorescence & W/O emulsion \\
\hline Trial 5 & pink globules & $\begin{array}{c}\text { formation of } \\
\text { two-layers }\end{array}$ & bulb did not light up & $\begin{array}{l}\text { red spots on blue } \\
\text { filter paper }\end{array}$ & fluorescence & W/O emulsion \\
\hline Trial 6 & pink globules & $\begin{array}{c}\text { formation of } \\
\text { two-layers }\end{array}$ & bulb did not light up & $\begin{array}{l}\text { red spots on blue } \\
\text { filter paper }\end{array}$ & fluorescence & W/O emulsion \\
\hline
\end{tabular}

Table 7. $\mathrm{IC}_{50}$ of T. cacao extract and T. cacao cream

\begin{tabular}{lccc}
\multirow{2}{*}{ Fraction } & \multicolumn{3}{c}{$\mathrm{IC}_{50}(\mu \mathrm{g} / \mathrm{mL})$} \\
\cline { 2 - 4 } & S. aureus & S. epidermidis & P. aeruginosa \\
\multirow{4}{*}{$\mathrm{CE}$} & $58.81 \pm 0.89$ & $72.58 \pm 1.24$ & $52.48 \pm 4.90$ \\
& $57.95 \pm 0.52$ & $72.86 \pm 1.08$ & $48.46 \pm 2.25$ \\
& $59.72 \pm 0.29$ & $71.22 \pm 1.57$ & $57.93 \pm 2.78$ \\
& $58.76 \pm 1.10$ & $73.67 \pm 3.47$ & $51.04 \pm 2.33$ \\
\hline \multirow{4}{*}{ Cream } & $60.30 \pm 2.54$ & $71.94 \pm 0.74$ & $58.60 \pm 1.49$ \\
& $59.40 \pm 1.80$ & $72.74 \pm 0.63$ & $58.81 \pm 2.12$ \\
& $58.33 \pm 1.96$ & $71.27 \pm 0.81$ & $59.97 \pm 2.04$ \\
& $63.17 \pm 2.07$ & $71.80 \pm 1.01$ & $57.02 \pm 0.45$ \\
\hline
\end{tabular}

of albino rabbits produced a slight erythema $(+1)$, after 4 hours of continuous exposure and after patch removal, on the site of application, that disappeared within 24 hours (Tables 8 and 9).

The same cream was also tested on the abraded group of albino rabbits. After 4 hours of continuous exposure, a slight erythema $(+1)$ was observed on the site of application but the erythema disappeared within 24 hours. Scab formation was observed from day 1 to day 7 and disappeared on day 8 (Tables 10 and 11).

\section{DISCUSSION}

The characterization tests of T. cacao pods and extract indicated that milled T. cacao pods contained more watersoluble constituents than alcohol-soluble constituents. Possible water-soluble constituents included carbohydrates, reducing sugars, hemicellulose, amino acids, flavonoids, tannins, and alkaloids such as theobromine. Alcohol-soluble constituents, on the other hand, included fatty acids, resins, sterols, flavonoids, terpenoids, and volatile substances such as isobutyl acetate. These chemical constituents could also be found in other parts of the T. cacao fruit such as the beans. ${ }^{17}$

To verify the presence of inorganic substances, such as minerals, the total ash content of milled T. cacao pods was determined. The quality of a raw material may depend on the concentration and the type of minerals it contains and may affect the extract and its stability. A high content of ash may indicate microbiological stability (due to retardation of microbial growth) or toxicity (due to high amount of heavy metals). Results from ash content determination of the sample, however, are not sufficient to conclude the presence 
Table 8. Effect of T. cacao cream on the abraded group albino rabbits (ITDI-STD, 2016)

\begin{tabular}{|c|c|c|c|c|c|c|c|c|c|c|c|c|c|}
\hline \multirow{2}{*}{ Rabbit number } & \multirow{2}{*}{ Sex } & \multicolumn{6}{|c|}{ Erythema and eschar formation } & \multicolumn{6}{|c|}{ Observation/Examination edema formation } \\
\hline & & $4 \mathrm{~h}$ & $24 \mathrm{~h}$ & $2 \mathrm{~d}$ & $3 \mathrm{~d}$ & $7 d$ & $14 \mathrm{~d}$ & $4 \mathrm{~h}$ & $24 \mathrm{~h}$ & $2 \mathrm{~d}$ & $3 \mathrm{~d}$ & $7 d$ & $14 \mathrm{~d}$ \\
\hline 1 & $\mathrm{~F}$ & 1 & 0 & 0 & 0 & 0 & 0 & 0 & 0 & 0 & 0 & 0 & 0 \\
\hline 2 & $\mathrm{~F}$ & 1 & 0 & 0 & 0 & 0 & 0 & 0 & 0 & 0 & 0 & 0 & 0 \\
\hline 3 & $\mathrm{~F}$ & 1 & 0 & 0 & 0 & 0 & 0 & 0 & 0 & 0 & 0 & 0 & 0 \\
\hline
\end{tabular}

Table 9. Effect of distilled water on the abraded group albino rabbits (ITDI-STD, 2016)

\begin{tabular}{|c|c|c|c|c|c|c|c|c|c|c|c|c|c|}
\hline \multirow{2}{*}{ Rabbit number } & \multirow{2}{*}{ Sex } & \multicolumn{6}{|c|}{ Erythema and eschar formation } & \multicolumn{6}{|c|}{ Observation/Examination edema formation } \\
\hline & & $4 \mathrm{~h}$ & $24 \mathrm{~h}$ & $2 \mathrm{~d}$ & $3 \mathrm{~d}$ & $7 \mathrm{~d}$ & $14 \mathrm{~d}$ & $4 \mathrm{~h}$ & $24 \mathrm{~h}$ & $2 \mathrm{~d}$ & $3 \mathrm{~d}$ & $7 \mathrm{~d}$ & $14 \mathrm{~d}$ \\
\hline 1 & $\mathrm{~F}$ & 1 & 0 & 0 & 0 & 0 & 0 & 0 & 0 & 0 & 0 & 0 & 0 \\
\hline 2 & $\mathrm{~F}$ & 1 & 0 & 0 & 0 & 0 & 0 & 0 & 0 & 0 & 0 & 0 & 0 \\
\hline 3 & $\mathrm{~F}$ & 1 & 0 & 0 & 0 & 0 & 0 & 0 & 0 & 0 & 0 & 0 & 0 \\
\hline
\end{tabular}

Table 10. Effect of T. cacao cream on the abraded group albino rabbits (ITDI-STD, 2016)

\begin{tabular}{|c|c|c|c|c|c|c|c|c|c|c|c|c|c|}
\hline \multirow{2}{*}{ Rabbit number } & \multirow{2}{*}{ Sex } & \multicolumn{6}{|c|}{ Erythema and eschar formation } & \multicolumn{6}{|c|}{ Observation/Examination edema formation } \\
\hline & & $4 \mathrm{~h}$ & $24 \mathrm{~h}$ & $2 \mathrm{~d}$ & $3 \mathrm{~d}$ & $7 d$ & $14 d$ & $4 \mathrm{~h}$ & $24 \mathrm{~h}$ & $2 d$ & $3 \mathrm{~d}$ & $7 \mathrm{~d}$ & $14 \mathrm{~d}$ \\
\hline 1 & $\mathrm{~F}$ & 1 & 0 & 0 & 0 & 0 & 0 & 0 & 0 & 0 & 0 & 0 & 0 \\
\hline 2 & $\mathrm{~F}$ & 1 & 0 & 0 & 0 & 0 & 0 & 0 & 0 & 0 & 0 & 0 & 0 \\
\hline 3 & $\mathrm{~F}$ & 1 & 0 & 0 & 0 & 0 & 0 & 0 & 0 & 0 & 0 & 0 & 0 \\
\hline
\end{tabular}

Table 11. Effect of distilled water on the abraded group albino rabbits (ITDI-STD, 2016)

\begin{tabular}{|c|c|c|c|c|c|c|c|c|c|c|c|c|c|}
\hline \multirow{2}{*}{ Rabbit number } & \multirow{2}{*}{ Sex } & \multicolumn{6}{|c|}{ Erythema and eschar formation } & \multicolumn{6}{|c|}{ Observation/Examination edema formation } \\
\hline & & $4 \mathrm{~h}$ & $24 \mathrm{~h}$ & $2 \mathrm{~d}$ & $3 \mathrm{~d}$ & $7 \mathrm{~d}$ & $14 \mathrm{~d}$ & $4 \mathrm{~h}$ & $24 \mathrm{~h}$ & $2 d$ & $3 \mathrm{~d}$ & $7 d$ & $14 d$ \\
\hline 1 & $\mathrm{~F}$ & 1 & 0 & 0 & 0 & 0 & 0 & 0 & 0 & 0 & 0 & 0 & 0 \\
\hline 2 & $\mathrm{~F}$ & 1 & 0 & 0 & 0 & 0 & 0 & 0 & 0 & 0 & 0 & 0 & 0 \\
\hline 3 & $\mathrm{~F}$ & 1 & 0 & 0 & 0 & 0 & 0 & 0 & 0 & 0 & 0 & 0 & 0 \\
\hline
\end{tabular}

of specific inorganic substances, such as minerals and heavy metals, hence, confirmatory tests must be conducted.

Loss on drying (LOD) was conducted on the pods to measure the amount of water and volatile substances when the sample is dried as specified in the Philippine Pharmacopeia I $\left(105^{\circ} \mathrm{C}\right)$. Although most of the volatile substances such as isobutyl acetate, are found in the T. cacao beans, it can be noted that the pods also contain volatile substances, and these may be responsible for the distinct sweet odor observed during the drying process. ${ }^{17}$ Cold maceration of milled $T$. cacao pods was performed and allowed to stand at 24 hours stored in a refrigerator $\left(4^{\circ} \mathrm{C}\right)$. The maceration was maintained at $4^{\circ} \mathrm{C}$ to prevent microbial growth. Freeze-drying of T. cacao extract was done to prevent its degradation. The actual \% yield of the $T$. cacao extract may possibly have constituents such as carbohydrates, reducing sugars, flavonoids, amino acids, flavonoids, alkaloids, and tannins, as confirmed by phytochemical screening.

Three aerobic bacterial strains ( $S$ aureus, $S$. epidermidis, and $P$ aeruginosa), that are representative causative agents of skin infection, were used for the antibacterial activity test based on National Committee for Clinical Laboratory Standards Manual for Antimicrobial Susceptibility Testing and on Clinical and Laboratory Standards Institute guidelines. ${ }^{15,16}$ Other bacterial strains responsible for skin infections such as Propionibacterium acnes and fungal strains were not included in the study.

Colorimetric method using 3,5-dimethylthiazol2-yl)-2,5-diphenyltetrazolium bromide or tetrazolium blue bromide (MTT) dye was performed for antibacterial activity testing. MTT is usually used for cell viability reduction assay wherein viable cells with active metabolism convert MTT into a purple colored formazan product with an absorbance from 500-570 $\mathrm{nm}$. The amount of formazan produced is directly proportional to the number of viable cells. ${ }^{17}$ In the case of this study, inhibition of bacterial growth was interpreted based on the quantity of formazan product present on the test sample. As shown in Figure 4, inhibition of bacterial growth could be seen even if it was still not measured quantitatively. The intensity of the color elicited by the formazan product can also be a contributing factor for determining which among the extract and its fractions have high antibacterial activity. The lighter the color, the greater the inhibition.

Determination of antibacterial activity was assessed through the half maximal inhibition concentration $\left(\mathrm{IC}_{50}\right)$. The $\mathrm{IC}_{50}$ indicates how much of a substance is needed to inhibit $50 \%$ of bacterial growth, and is usually expressed in molar concentration. Determination of $\mathrm{IC}_{50}$ is based on the calculation of the percent inhibition at a given concentration 
point $(30,70$, and $150 \mu \mathrm{g} / \mathrm{mL})$. The lower the $\mathrm{IC}_{50}$ value, the higher antibacterial activity is observed.

The T. cacao extract was subjected to partitioning to separate possible constituents that have antibacterial activity. This process may either improve or reduce the antibacterial activity of the sample. Based on the results, separation had occurred, since differences on the result of the phytochemical screening and antibacterial activity were observed.

It can be noted that through liquid-liquid partitioning, the antibacterial activity of $\mathrm{CE}$ and $\mathrm{CE} 1$ against 3 bacterial strains increased. The $\mathrm{IC}_{50}$ of $\mathrm{CE} 1$ was lower than that of $\mathrm{CE}$, therefore a higher antibacterial activity was observed in CE1. Possible constituents that may be responsible for the antibacterial activity were flavonoids, alkaloids, and tannins. The lower antibacterial activity observed in $\mathrm{CE}$ as compared to CE1 may be attributed to steric hindrance due to the presence of carbohydrates and reducing sugars that may be attached to other constituents. Among the fractions, the CE3 fraction had the least antibacterial activity. This fraction only contained cardiac glycosides, and this may have not contributed much in the antibacterial activity, since it has the highest $\mathrm{IC}_{50}$ among the fractions tested. It can be noted that cardiac glycosides need to be synergistically paired with other constituents to elicit antibacterial activity.

No comparison of the $\mathrm{IC}_{50}$ of the fractions and clindamycin (Cln) as positive control was performed, as the latter was only used to validate if the antibacterial activity test was working.

Based on the result, the formulated cream did not affect the antibacterial activity of the $\mathrm{CE}$ extract. The excipients added did not alter the activity of the extract.

Although a slight erythema was observed both in the non-abraded and abraded groups, T. cacao cream was still considered as non-irritant since the erythema disappeared within 24 hours after patch removal. The T. cacao cream did not cause edema. Moreover, the slight erythema observed within 4 hours after application of cream did not result to eschar formation in both groups.

No further erythema, eschar, and edema formation was observed within the 14-day period of testing. Scab formation was attributed to the healing of abrasions of the skin of albino rabbits.

Since T. cacao cream is intended only for skin infection, chronic toxicity study is not necessary.

\section{CONCLUSION}

This study confirmed the antibacterial activity of the cream formulated from $T$. cacao pod aqueous extract. The extract as well as its fractions exhibited antibacterial activity against three bacterial strains, based on their $\mathrm{IC}_{50}$ value. The T. cacao cream produced a water-in-oil, non-irritant cream with a retained antibacterial activity of the extract, and acceptable physical attributes.
The study recommends to (1) include bacterial strains, such as Propionibacterium acnes and other species that are responsible for skin infection in the antibacterial activity testing; (2) conduct comparative analysis of different antibacterial activity tests between broth microdilution method, and reduction assays using MTT and resazurin dyes; and (3) perform skin sensitization, skin corrosion, and skin sensitivity tests to ensure the intended safe use of the T. cacao pod aqueous extract on the skin.

\section{Statement of Authorship}

All authors participated in data collection and analysis, and approved the final version submitted.

\section{Author Disclosure}

All authors declared no conflict of interest.

\section{Funding Source}

This paper was funded by the authors.

\section{REFERENCES}

1. Herbinger KH, Siess C, Nothdurft HD, von Sonnenburg F, Loscher T. Skin disorders among travelers returning from tropical and non-tropical countries consulting a travel medicine clinic. Trop Med Int Health. 2011; 16(11):1457-64.

2. The Philippine Dermatological Society [Internet]. Skin Health. 2016 [cited 2016 Mar]. Available from http://pds.org.ph/category/skinhealth/.

3. Oakley A. Bacterial Skin Infection [Internet]. 2002 [cited 2016 Feb]. Available from http://www.dermnetnz.org/bacterial/.

4. Shenefelt PD. Herbal Treatment for Dermatologic Disorders. In: Benzie IFF, Wachtel-Galor S, eds. Herbal Medicine: Biomolecular and Clinical Aspects, 2nd ed. Boca Raton (FL): CRC Press/Taylor \& Francis; 2011.

5. Valle DL Jr, Andrade JI, Puzon JJM, Cabrera EC, Rivera WL. Antibacterial activities of ethanol extracts of Philippine medicinal plants against multidrug-resistant bacteria. Asian Pac J Trop Biomed. 2015; 5(1):930-7.

6. Singh N, Datta S, Dey A, Chowdhury AR, Abraham J. (2015). Antimicrobial activity and cytotoxicity of Theobroma cacao extracts. Der Pharmacia Lettre. 2015; 7(7):287-94.

7. Santos RX, Oliveira DA, Sodre GA, Gosmann G, Brendel M, Pungartnik C. (2014). Antimicrobial activity of fermented Theobroma cacao pod husk extract. Genet Mol Res. 2014; 13(3):7725-35.

8. Department of Agriculture Bureau of Plant Industry [Internet]. Cacao Production Guide. 2016 [cited 2017 Aug]. Available from http:// bpi.da.gov.ph/bpi/index.php/production-guide/474-production-guidecacao.

9. Daud Z, Kassim ASM, Aripin AM, Awang H, Hatta MZM. (2013). Chemical Composition and Morphological of Cocoa Pod Husks and Cassava Peels for Pulp and Paper Production. Aust J Basic Appl Sci. 2013; 7(9):406-11.

10. Bureau of Food and Drugs. Philippine Pharmacopeia I. Metro Manila: Himiko Arts and Concepts; 2004. pp. 122-130, 146-149, 191-206.

11. World Health Organization. WHO Guidelines for Assessing Quality of Herbal Medicines with Reference to Contaminants and Residues.Geneva: World Health Organization; 2007. pp. 7-10.

12. Silva G, Lee I, Kinghorn A. Special Problems with the Extraction of Plants. In: Cannell R, ed. Natural Products Isolation. New Jersey: Humana Press; 1998. pp. 343-363. 
13. United States Pharmacopeial Convention, Inc. United States Pharmacopeia 35th Edition and National Formulary 30th Revision. Maryland. United States Pharmacopeial Convention, Inc., 2012. pp.56-57.

14. Coyle MB. National Committee for Clinical Laboratory Standards Manual of Antimicrobial Susceptibility Testing [Internet]. 2005 [cited 2015 Dec]. Available from https://www.google.com.ph/url?sa $=t \& r c t=j \& q=\& e s r c=s \&$ source $=w e b \& c d=1 \& v e d=0 a h U K E w i C 7 q m l 6$ NDJAhVJyWMKHcdfAX4QFgggMAA\&url=http\%3A\%2F\%2Fw ww.researchgate.net\%2Ffile.PostFileLoader.html\%3Fid\%3D555dd7 066225ffbe808b458c\%26assetKey\%3DAS\%253A273781250035720 \%25401442285944459\&usg=AFQjCNEPgv73-alYLFf9DO59O4pq PvP3Qg\&sig2=ZNs7jfgq7_WI3YvxrOJwNQ.
15. Clinical and Laboratory Standards Institute. [Internet]. 2012 [cited 2015 Dec]. Methods for Dilution Antimicrobial Susceptibility Tests for Bacteria That Grow Aerobically; Approved Standard, 9th Edition. Available from: http://antimicrobianos.com.ar/ATB/wp-content/ uploads/2012/11/03-CLSI-M07-A9-2012.pdf.

16. Rodriguez-Campos J, Escalona-Buendia HB, Orozco-Avila I, Lugo-Cervantes E, Jarmillo-Flores ME. Dynamics of volatile and non-volatile compounds in cocoa (Theobroma cacao L.) during fermentation and drying processes using principal components analysis. Food Res Int. 2011; 44(1):250-8.

17. Riss TL, Moravec RA, Niles AL, Duellman S, Benink HA, Worella TJ, et al. Cell Viability Assays. In: Sittampalam GS, Grossman A, Brimacombe K, et al., eds. Bethesda (MD): Eli Lilly \& Company and the National Center for Advancing Translational Sciences; 2013.

\section{Have you read the current trends in} Medical and Health Research in the Philippines?

\section{Acta Medica Philippina The National Health Science Journal}

Access Online: actamedicaphilippina.upm.edu.ph 